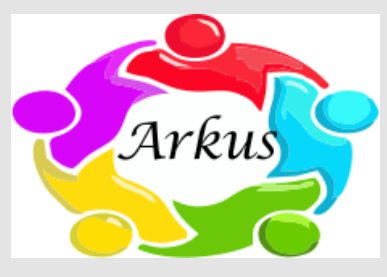

\title{
The Loss of Nandong Culture in Sambay Village, West Aceh: A Sociology Perspective
}

\section{Andi Fadinul ${ }^{*}$}

${ }^{1}$ Sociology Study Program, Faculty of Social and Political Science, Universitas Teuku Umar, Meulaboh, Indonesia

\section{A R T I C L E I N F O}

\section{Keywords:}

Traditional song

Cultural heritage

Poetry

Nandong art

\section{Corresponding author:}

Andi Fadinul

E-mail address:

andi_fadinul@gmail.com

The author has reviewed and approved the final version of the manuscript.

\section{A B S T R A C T}

Nandong is a song usually sung by Padang people who come to trade to the island of Simeulue. Nandong poetry is sung in the form of rhymes and describes the story of human life, but over time, the poems conveyed by intelligent people are compiled into art called Nandong. Nandong poetry tells the story of human life and is displayed in wedding events to be entertained and give advice to those who are married. However, at this time, the preservation of Nandong culture seems to be fading due to the development of modern musical instruments so that local culture is rarely displayed. This study will describe the factors causing the loss of Nandong culture in Sambay village, West Aceh.

https://doi.org/10.37275/arkus.v6i2.84

\section{Introduction}

Many human ideas and ideas live together in a society, giving soul to that society. These ideas are always related to one another to form a system. In Indonesia, other terms are very appropriate to refer to the ideal form of this culture, namely customs or customs for the plural form. The second form of culture is called the social system, concerning the patterned actions of humans themselves. This social system consists of human activities that interact, relate, and associate with one another. ${ }^{1-3}$

The people of Sambay village face new technology and foreign culture, dragging them into the new culture. Currently, the Nandong cultural arts that are proud of by the people of Sambay village are almost invisible in community celebration parties and people's parties. Whether or not Nandong culture is lost or not depends on the attitude of the people themselves. This study was to describe the factors causing the loss of Nandong culture in Sambay village, West Aceh.

In human life, there is a view of a group or group with a sense of building that always wants progress and reforms according to the demands of the times. In addition, it is also supported by the views of a 
group of optimistic people, which is interpreted as a group of people who understand that tomorrow in the future there will be a brighter day, so driven by the psychological sense of optimism, they will always be careful in their actions bring the flow of society that tends to move forward and change. ${ }^{4-7}$

According to Wibert, social and cultural change is not a symptom of modern society but a universal thing in the experience of human life. Social change is a variation of accepted ways of life, either because of geographical conditions, material culture, population composition, ideology, or diffusion in society. From the above definition, it can be concluded that social and cultural change is not a change in society towards modernity, but rather the experience of human life and ways of human life that have been accepted by society, both socially and culturally in society. ${ }^{8-10}$

The form of culture is divided into three: the first form is the ideal form of culture. It is abstract, cannot be touched or photographed. Its location is in the minds of the citizens of the community where the culture concerned lives. If the community members express their ideas in writing, then the location of the ideal culture is often found in the essays and books by the writers of the community concerned. The ideal culture is also stored in floppy disks, archives, microfiche collections, computer cards, and tapes. ${ }^{10-}$ 12

\section{Methods}

The research method used is descriptive qualitative because this research was conducted by collecting, processing, presenting, and describing the research results and social phenomena. The source of data in this study is data obtained from observations and interviews with several selected resource persons in the study. The selection of several critical informants in order to obtain more indepth and accurate information about the issues to be discussed, while informants who are part of the population are selected through snowball sampling. The informants in this research are as follows: 2 geuchik (Nandong artists), and six people from Sambay village. Data analysis used a qualitative descriptive method, where the discussion of the research and the results were described in words based on the empirical data obtained. The data obtained in this study is qualitative, so the data analysis used is non-statistical.

\section{Results and discussion}

Some view society from a cultural point of view because culture is the most crucial part of society. Some view society as groups because groups are the elements that determine people's lives. Along with the times, many changes occur in people's lives. The economy, society, and culture are part of the changes caused by the emergence of a new culture. However, humans must be more careful in the presence of a new culture, thus dragging the culture. which has been passed down by their ancestors. The ancestral heritage entrusted to the current generation is to be maintained so that it does not disappear because this culture is one of the identities of a nation for its cultural diversity. The existing culture must be maintained so that the next generation can enjoy the creations of their predecessors so that the generation knows that their predecessors and themselves now have a culture that is produced by an invaluable thought.

The fate of traditional culture is gradually fading; due to the lack of public concern for preserving this culture, traditional culture seems only as a legacy to be remembered, not to be preserved. As if traditional culture is not under the times. Moreover, make the culture passed down just as a story that the predecessors had created a culture. However, the existing culture must be maintained and preserved as an asset in the future for generations to come.

However, on the other hand, new cultures keep coming; if humans are not very good at maintaining 
their culture, the culture they have may disappear, along with the arrival of a new culture. This is where humans formed in society do everything they can to maintain their culture so that what is inherited by their predecessors remains and can be enjoyed by the next generation.

People faced with the emergence of technology that gives birth to outside culture are dragged into a new culture. The people of Sambay village also experience this, where the art of Nandong culture that the Semeulue people are proud of is now almost invisible. Both in community celebration parties, as well as people's parties. Whether or not Nandong culture is lost or not depends on the attitude of the people themselves.

So it is not surprising that the people of Gampong village face many things regarding the almost disappearance of Nandong culture; one of the causes of the almost disappearance of Nandong culture in the community of Sambay village, the absence of cadre can be seen from the never again being trained for the younger generation, as expressed by one informant Raswin tuha phuet in Sambay village. Nandong is now very rarely shown, not the people's desire to preserve Nandong culture. Likewise, training for young people in Gampong Sambay is no longer carried out. The lack of cadre or successor for young people has caused the Nandong culture to disappear gradually.

Sarisuddin expressed the same thing as a Nandong artist. Especially in Sambay village, Nandong art is almost gone, frankly, as one of the artists of Nandong. Very little interest from the people of Gampong Sambay in participating in the preservation of Nandong, it can be seen that very few people, both young and old, understand Nandong. The cadre for youth has never been taken seriously, meaning that it was carried out for the successors of Nandong artists. The cause of Nandong culture is starting to disappear due to the narrow space of movement carried out by the community in preserving Nandong, which is motivated by the lack of community participation in preserving Nandong culture, this makes the number of successors who can play Nandong art be counted, and the number of those who can play Nandong can be counted. From the informants' responses, it can be concluded that the cause of the disappearance of Nandong culture is due to the absence of cadre by Nandong artists for Gampong Sambay teenagers. There is no Nandong practice on weekdays, so Nandong is very difficult to find in Sambay.

The lack of community participation in Sambay is also caused by the low participation of the community in the art of Nandong, and it causes very few people who are proficient in playing Nandong in Gampong Sambay, who can play Nandong there are only a few people. Generally, those who can play the art of Nandong are old, and This proves that there is no cadre being carried out in Gampong Sambay for Nandong art.

The emergence of modern musical arts sometimes negatively impacts traditional arts that are owned in rural areas. Of course, the impact is the erosion of the old culture and the emergence of a new culture. So as to make the culture that has been inherited by the predecessors left without any direction and purpose. Local cultural arts should still be maintained, considering that local cultural arts are one of the heritages that must be preserved.13-16

The loss of Nandong culture is due to the low participation of the community in preserving the Nandong art culture, the lack of public interest in using Nandong as public entertainment at parties at community homes, with the infrequent request for Nandong to be lost in the Nandong Village community. Another cause that made Nandong disappear in Sambay was the emergence of modern music such as the keyboard. The Sambay community preferred modern music rather than Nandong music; thus, Nandong was rarely performed even at people's homes. 
The youth should guard the culture inherited by the previous ancestors because the youth are the successors who continue to preserve what was left behind by their predecessors. The preservation of this culture must be realized by caring and carrying out activities to show other arts such as Nandong art so that the wider community knows Nandong. However, if the youth do not have the nature to preserve culture such as Nandong culture, then who else will continue their ancestral heritage? But the attitude of the Gampong Sambay youth is also weak in preserving Nandong culture, as stated by one of Zinman's informants, one of the youth of Sambay against starting loss of Nandong culture in Sambay.

The weakness of the Gampong Sambay community in preserving Nandong culture will result in the loss of the identity of thevillage itself, considering that Nandong is a work created by ancestors for future generations. Because the people of Gampong Sambay must do something to preserve the Nandong culture, if there is no training on the art of Nandong then Nandong will be lost as a culture belonging to Sambay.

Admittedly or not, along with the times and the emergence of modernization, many traditional cultures are lost by the presence of new cultures, which continue to arrive without being able to be dammed, from all directions coming and ready to be offered to humans to enjoy the results created from outside. This makes humans required to think and determine their attitude in accepting new culture.

Preservation of the existing culture is not just doing these cultural activities, but the community must have the attitude to continue to strive to maintain the heritage; this attitude can be realized by creating a cadre for the young to know more about Nandong art so that the young can know that there is a heritage from its predecessor. ${ }^{17,18}$

Culture is an essential element in the development process or the sustainability of a village. Development is nothing but a conscious effort to create living conditions for people who live in a society for the better. Development is human intervention in the natural environment, both the natural physical environment and the socio-cultural environment. On the contrary, setbacks are natural and physical declines and their social and cultural environment, but the attitudes of the people themselves sometimes cause social and cultural changes in society.

The loss of culture owned by Sambay towards Nandong art is caused by the entry of new cultures, such as the keyboard group where the music has shifted the old culture, the culture born by the predecessors that should be guarded so as not to disappear. However, this happened because the attitude of the Sambay community did not want to preserve their own culture. The lack of participation of the Sambay community in the preservation of Nandong is one of the causes of the loss of Nandong culture, the lack of Nandong fans can be seen from the lack of Nandong being seen at celebrations at people's homes. This is following the expression of Miriam Budiarjo. A low level of participation is generally considered a bad sign because it can be interpreted that many citizens are not paying attention to a problem.

One of the experts stated above proves that Sambay's low participation in issues such as the Nandong problem, which is now almost invisible, can have disappeared in the Sambay community. However, the community did not do anything to preserve the existing culture, namely Nandong. This low community participation resulted in the displacement of the existing culture with the new culture. The Nandong culture in Sambay only remained a remembered culture and was not carried out by deeds. The people of Sambay should conduct cadre for the youth of Sambay, for the art of Nandong so that it does not disappear. It is considering that there are very few Nandong players in Sambay. That is why it is necessary to introduce Nandong to the young so that the intelligent and proficient generation 
playing Nandong continues to exist in Sambay Village. ${ }^{19-21}$

\section{Conclusion}

The emergence of modern music, the absence of Nandong art training carried out by the Sambay community for young people to create a generation that knows Nandong, and the lack of Nandong artists.

\section{References}

1. Akhwat, Perubahan Sosial Dan Budaya, PT. Express, Jakarta. 2010.

2. Ahmadi, A. Psikologi Sosial. Edisi Revisi. Rineka Cipta. Jakarta. 2007.

3. Arikunto S. Prosedur PenelitianRineka Cipta. Jakarta. 2006.

4. Syani A. Keberagaman Budaya Indonesia, Media Press, Jakarta. 1995.

5. Burhan M. Penelitian Kualitatif : Ekonomi, Komunikasi, Kebijakan Publik dan Ilmu Sosial Lainnya. Kencana Prenada Media Group. Jakarta. 2008

6. Nadjib EA. Terus Mencoba Budayđanding. Pustaka Pelajar. YogyakartaIndonesia. 1987.

7. Emzir. Metodologi Penelitian Kualitatif Analisis Data. PT Raja Garafindo Persada. Jakatra. 2010.

8. Faisal S. Format-format Penelitian sosial, Dasar-Dasar dan Aplikasi. PT Rajerarafindo Persada. Jakatra. 2005.

9. Giddens, A, Jonatan T. The Theory Today, Panduan Sistematis
Tradisi dan Tren Terdepan Teori Sosial. Pustaka Pelajar Yogyakarta. 2008.

10. Jacobus Ranjabar, Sosiologi, Reneka Cipta, Jakartra. 2008.

11. Koentjaraningrat. Pengantar Ilmu Antropologi. Rineka Cipta Jakarta. 2006.

12. Miriam Budiardjo. Dasar-Dasar Ilmu Politik. PT. Garamedia Pustaka Utama. Jakarta. 2008.

13. Malihah, Masyarakat Dalam Kebudayaan, Graha Cipta, Jakarta. 2003.

14. Rush, Michael \& Phillip Althoff. Pengantar Sosiologi Politik. PT Raja Garafindo Persada. Jakatra. 2007.

15. Sugiyono. Metode Penelitian Kuantitatif, Kualitatif dan $\mathrm{R} \& \mathrm{D}$, Bandung: Alfabeta. 2011

16. Sunaryadi. Tantangan Dan Perubahan, Arita Press, Bandung. 2000.

17. Sunarto, Kamanto. Pengantar Sosiologi. Edisi Revisi. Fakultas Ekonomi Universitas Indonesia. Jakarta. 2004.

18. Soekanto, Soerjono. Sosiologi Suatu Pengantar. PT Raja Grafindo Persada. Jakarta. 2006.

19. Sztompka, Piort. Sosiologi Perubahan Sosial. Prenada Media. Jakarta. Wiryohandoyo, Sudarno. 2002. Perubahan Sosial, Sketsa Teori dan Refleksi. 2005.

20. Metodologi Kasus Indonesia. PT Tiara Wacana. Yogyakarta.

21. Yopy Andri, Nandong Seni Tradisional Simeulue Yang Terlupakan, Graha Cipta. Yogyakarta. 2009. 